\title{
Esra Mirze Santesso, Disorientation: Muslim Identity in Contemporary Anglophone Literature
}

Lindsey Moore

\section{Q OpenEdition}

1 Journals

Electronic version

URL: https://journals.openedition.org/ces/5810

DOI: $10.4000 /$ ces.5810

ISSN: 2534-6695

Publisher

SEPC (Société d'études des pays du Commonwealth)

\section{Printed version}

Date of publication: 1 April 2014

Number of pages: 123-124

ISSN: 2270-0633

\section{Electronic reference}

Lindsey Moore, "Esra Mirze Santesso, Disorientation: Muslim Identity in Contemporary Anglophone Literature", Commonwealth Essays and Studies [Online], 36.2 | 2014, Online since 15 April 2021, connection on 19 July 2021. URL: http://journals.openedition.org/ces/5810 ; DOI: https://doi.org/ $10.4000 /$ ces. 5810

This text was automatically generated on 19 July 2021 .

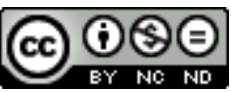

Commonwealth Essays and Studies is licensed under a Licence Creative Commons Attribution - Pas d'Utilisation Commerciale - Pas de Modification 4.0 International. 


\title{
Esra Mirze Santesso, Disorientation: Muslim Identity in Contemporary Anglophone Literature
}

\author{
Lindsey Moore
}

\section{REFERENCES}

Esra Mirze Santesso. Disorientation: Muslim Identity in Contemporary Anglophone Literature. Houndmills: Palgrave Macmillan, 2013. 223 p. ISBN (hb): 9781137281715, £50.

Disorientation: Muslim Identity in Contemporary Anglophone Literature significantly contributes to work in postcolonial literary studies on Muslim identity, particularly within immigrant and/or minority contexts. ${ }^{1}$ Its closest affiliates are Amin Malak's Muslim Narratives and the Discourse of English (Albany: SUNY Press, 2004) and Geoffrey Nash's Writing Muslim Identity (London: Continuum, 2012); it is also informed by the work of Claire Chambers. ${ }^{2}$ Mirze Santesso convincingly updates what analysis exists in this area, making a cogent case for the distinctive qualities of the work assessed particularly in its gendered and religious dimensions - in contrast with work of an earlier generation of writers of South Asian and Arab origin, such as Hanif Kureishi, Salman Rushdie and Ahdaf Soueif. The topical significance of fiction that foregrounds "deradicalised ways of being a Muslim" (53) needs no elaboration. The emphasis on women's religious trajectories, loyalties, and compromises is to be applauded and moves the discussion beyond single axis and static conceptions of "identity."

The author focuses on the "disorienting" experiences of first-generation female Muslim migrants to Britain, as evoked in post-9/11 narratives. The concept of disorientation proves surprisingly capacious, facilitating not only a synthesis of fiction by Monica Ali, Leila Aboulela and Fadia Faqir but, more surprisingly, by Canada-based author Camilla Gibb, second-generation British-Asian writers in whose fiction "disorientation" has a more spectral presence, and one male author (Nadeem Aslam). The premise, to redress 
postcolonial critical concepts such as hybridity, mimicry, and transnationalism - tropes so established as to be clichés - is initially worrisome,$^{3}$ as is a persistent stylistic (though happily not analytical) tendency to use generalizing categories such as "the Muslim woman" and "the Islamic veil." However, "disorientation," conceived as "a flexible positionality" with varied (ir)resolutions (181), produces sensitive and varied readings of character, theme and plot in single-text focused chapters. Organizing postcolonial tropes are rigorously reframed through specific references to literary material, thereby emphasizing the shortcomings of established theory with respect to gender, class and religious identity.

The author thus persuasively justifies her close focus on one concept, though the reader is left wondering what fiction might resist appropriation under this rubric. Shelina Zahra Janmohamed's Love in a Headscarf (London: Aurum Press, 2009) arguably does something different from the "young adult" works discussed here and reference could have been made to Robin Yassin-Kassab's The Road from Damascus (London: Hamish Hamilton, 2008), which is structured around male disorientation. Given the limited familiarity of the selected writers to a general (or even academic) audience, wider reference to their work would also be a boon. I am not convinced that in Fadia Faqir's work as a whole, Islam - as opposed to Arab/Bedouin/Levantine culture - "takes centre stage and becomes the primary lens through which to examine female agency" (114). Moreover, the author uses Faqir's U.S. title The Cry of the Dove, rather than the U.K. title My Name is Salma: reference to the latter would have enabled discussion of form, which tends to be under-explored in the book as a whole, though there is some reference to genre.

These quibbles aside, the book provides distinctive readings throughout, both of texts that have received a reasonable amount of critical attention - a chapter on Leila Aboulela's Minaret (2005) and a section on the ending of Monica Ali's Brick Lane (2003) are particularly strong - and of others that have received little attention to date. The incorporation of Gibb's Sweetness in the Belly (2005), which foregrounds Sufism, "regionalism cosmopolitanism" and rerooting, is particularly inspired. Overall, Disorientation is an admirable contribution to the postcolonial literary field and, less directly but just as importantly, to conceptions both of British multiculturalism and of contemporary Muslim identities in transnational contexts.

\section{NOTES}

1. This enables development (not exclusively) of another under-represented sub-category in postcolonial literary studies, which is Anglophone Arab writing.

2. However, the author surprisingly does not refer to Chambers' British Muslim Fictions: Interviews with Contemporary Writers (Houndmills: Palgrave Macmillan, 2011).

3. Indeed, the early stages of the book frame postcolonial studies in an oddly dated manner, suggesting, for example, that it "currently foregrounds the emergence of national consciousness and native decolonization" (6). 